\title{
'Newes also came by Letters': Functions and Features of Epistolary News in English News Publications of the Seventeenth Century
}

\author{
Nicholas Brownlees
}

I

From Upsall in Sweden, March 10.

This Post brought no Letters to us from England; so that we are still in the dark, as to the success of the Treaty between England and the United Provinces. ${ }^{1}$

These first lines of a news dispatch that was published in the weekly news pamphlet Mercurius Politicus in 1654 illustrate the fundamental importance of correspondence in the transmission of news in seventeenth-century Europe. With no letters arriving from England, the news writer in Uppsala did not know how treaty negotiations between England and the United Provinces were developing. Without letters the news writer was indeed 'in the dark'. In the correspondent's quest for information as to how events in Europe were unfolding, no mention is made of other possible news sources such as print or oral news: all that counts are the letters.

However, the lines from Mercurius Politicus not only exemplify the importance of epistolary news for an individual's understanding of seventeenthcentury European affairs and politics; the dispatch also alludes to the use of epistolary news as a source for print news. The news from Uppsala is based on a letter sent by someone from that town. Thus, the published information from Sweden refers to correspondence which had not arrived from England: a news item which in turn is sent back by letter to England, and then subsequently published in Mercurius Politicus. Like all seventeenth-century news publications, Mercurius Politicus, England's foremost weekly newsbook of the 1650 s, relied extensively on letters for its own news. ${ }^{2}$ The letters could be either

1 Mercurius Politicus, 13 April 1654 (Lancaster Newsbooks Corpus; hereafter LNC).

2 For information about Mercurius Politicus and its editor, Marchamont Nedham, see Joad Raymond, "A Mercury with a Winged Conscience": Marchamont Nedham, monopoly and censorship', Media History, 4.1 (1998), pp. 7-18. For monographs on the press in seventeenth

(C) NICHOLAS BROWNLEES, 2016 | DOI 10.1163/9789004277199_018

This is an open access chapter distributed under the terms of the Creative Commons Attribution-

Noncommercial-NoDerivatives 3.o Unported (CC-BY-NC-ND 3.o) License. 
domestic or foreign, of an official nature or private, sometimes arriving directly at the publisher's desk or more probably amounting to the final stage of a much more circuitous route. Whatever their origin and background, and whichever network they belonged to, they could provide a very important source of news for seventeenth-century news editors. It is this interrelationship between correspondence and published news that I shall examine in the present chapter. $^{3}$

century Britain see, Peter Fraser, The Intelligence of the Secretaries of State and their Monopoly of Licensed News 1660-1688 (Cambridge: Cambridge University Press, 1956); Joseph Frank, The Beginnings of the English Newspaper, 1620-1660 (Cambridge, MA: Harvard University Press, 1961); James Sutherland, The Restoration Newspaper and its Development (Cambridge: Cambridge University Press, 1986); C. John Sommerville, The News Revolution in England: Cultural Dynamics of Daily Information (Oxford: Oxford University Press, 1996); Joad Raymond, The Invention of the Newspaper: English Newsbooks 1641-1649 (Oxford: Oxford University Press, 1996); Joad Raymond, Pamphlets and Pamphleteering in Early Modern Britain (Cambridge: Cambridge University Press, 2003); Jason Peacey, Politicians and Pamphleteers: Propaganda during the English Civil Wars and Interregnum (Aldershot: Ashgate, 2004);Jason McElligott, Royalism, Print and Censorship in Revolutionary England (Woodbridge: Boydell \& Brewer, 2007); Jayne Boys, London's News Press and the Thirty Years War (Woodbridge: Boydell \& Brewer, 2011); and Nicholas Brownlees, The Language of Periodical News in Seventeenth-Century England (Newcastle: Cambridge Scholars Press, 2014 [2011]).

3 Although the role of letters in the dissemination of news has received attention in recent years, little research has been carried out on the focus of the present chapter, that is, the explicit referencing in English periodical news publications to letters as sources of news reports. For this latter aspect, see Gary Schneider, The Culture of Epistolarity: Vernacular Letters and Letter Writing in Early Modern England 1500-1700 (Newark, DE: University of Delaware Press, 2005), p. 207; Nicholas Brownlees, 'Capt. Badiley's answer unto Capt. Appleton's remonstrance (1653): The recontextualisation in print of private correspondence', in The Language of Public and Private Communication in a Historical Perspective, eds. Nicholas Brownlees, Gabriella Del Lungo and John Denton (Newcastle: Cambridge Scholars Press, 2010), pp. 194-215; Brownlees, Language of Periodical News, pp. 12-24, 125-31; Andrew Pettegree, The Invention of News: How the World Came to Know About Itself (London: Yale University Press, 2014), pp. 316-8. For more general analyses on the kinds of letters that were published in news publications and how the epistolary form rendered the content more direct, authentic or simply interesting, see Ian Atherton, "The itch grown a disease": Manuscript Transmission of News in the Seventeenth Century', in News, Newspapers, and Society in Early Modern Britain, ed. Joad Raymond (London: Routledge, 1999), pp. 39-65; Cecile Jagodzinski, Privacy and Print: Reading and Writing in Seventeenth-Century England (Charlottesville: University of Virginia Press, 1999), pp. 74-93; Raymond, Pamphlets and Pamphleteering, pp. 214-18; Schneider, The Culture of Epistolarity, pp. 143-82, 201-21; David Randall, Credibility in Elizabethan and Early Stuart Military News (London: Pickering \& Chatto, 2008), pp. 121-50. 
The role of letters in the transmission of news will be examined by means of a corpus-based analysis of electronically-readable corpora of seventeenthcentury English print news. Through an examination of concordance lines containing the search terms 'letter $\{\mathrm{s}\}$ ', it is possible to gain insight into, first, the networks through which domestic and foreign epistolary news reached the English publisher, secondly, the added value epistolary news could give to the reliability and authenticity of the published news content, and, thirdly, the manner in which news in epistolary form could impact on the readers' understanding of Europe. My analysis of these topics will also involve consideration of general methodological issues regarding the compilation and use of machine-readable news corpora in the study of news networks in Early Modern Europe.

The three corpora consulted are the Florence Early English Newspapers Corpus (FEEN), the Lancaster Newsbooks Corpus ( $L N C$ ), and the Zurich English Newspaper Corpus (ZEN). In total, they contain more than 1.3 million words of digitised news texts, comprising foreign news corantos of 1620-41, Civil War and Interregnum newsbooks of the $1640 \mathrm{~s}$ and $1650 \mathrm{~s}$, and the London Gazette and other periodical newspapers from 1671-91.

The FEEN corpus covers the period from 1620-49. Consisting of 256,000 words, the collection of print news texts is divided into subcorpora, including the first corantos of 1620-1, which were more or less literal translations of previously published Dutch newssheets; the serialised corantos between 1622-41; five well-known newsbooks spanning 1642-9; and the adversarial Civil War newsbooks Mercurius Aulicus and Mercurius Britanicus in 1643-4. ${ }^{4}$

The Lancaster Newsbooks Corpus is very different in size and focus from the FEEN corpus. Rather than including selected texts over an extended period of time, it includes a very large collection of news and spoof news texts over a short time span. The period in question is December 1653 until the end of May 1654, and the part of the corpus containing the mainstream news publications amounts to 870,000 words. The newsbooks included in the corpus are $A$ Perfect Account, A Perfect Diurnall of Some Passages and Proceedings, Certaine Passages of Every Dayes Intelligence, Mercurius Aulicus, Mercurius Politicus, Perfect Diurnall

4 For a description of the FEEN corpus, see Nicholas Brownlees, 'The beginnings of periodical news (1620-1665)', in News as Changing Texts: Corpora, Methodologies and Analysis, ed. Roberta Facchinetti, Nicholas Brownlees, Birte Bös and Udo Fries (Newcastle: Cambridge Scholars Press, 2012), pp. 5-48. In its extended form the FEEN corpus covers the period $1620-53$, but the version which is used for the present analysis includes the years $1620-49$. 
Occurrences, Several Proceedings of State Affairs, The Faithful Scout, The True and Perfect Dutch Diurnall, The Weekly Intelligencer and The Weekly Post. ${ }^{5}$

The third corpus that I have consulted, the ZEN corpus, comprises a selection of periodical English newspapers from 1671 until the end of the eighteenth century. Numbers from the years 1671,1681 and 1691 , amounting in all to 184,000 words, were examined for the analysis. ${ }^{6}$ Most of the corpus is made up of the London Gazette, but other numbers include The Currant Intelligence, The Domestick Intelligence, The Impartial Protestant Mercury, The Pacquet of Advice from France and The Protestant (Domestick) Intelligence.

Both the FEEN and Lancaster Newsbooks corpora have the same URL and can be analysed with the same corpus analysis tool, Corpus Query Processor (CQPweb). ${ }^{7}$ The fact that the $Z E N$ corpus is not online, and requires a different corpus analysis tool, exemplifies a methodological difficulty that sometimes arises in corpus-based diachronic analysis. Although an increasing number of digitised historical corpora is becoming available, such corpora are often accessed in different ways and require a variety of analytical tools. Thus, in this analysis, while $F E E N$ and $L N C$ were analysed by CQPweb, Corpus Presenter was used for the examination of $Z E N .^{8}$

In the examination of 'letter\{s\}' in $F E E N, L N C$ and $Z E N$, the concordance line can be expanded to incorporate more than the standard few words to the left and right of the search term. In FEEN and $L N C$ the surrounding text can run

5 For further information on the $L N C$ corpus, and how it can be used for discourse analyses of news reporting in the 1650 s, see Sheryl Prentice and Andrew Hardie, 'Empowerment and disempowerment in the Glencairn Uprising: A corpus-based critical analysis of early modern English news discourse', Journal of Historical Pragmatics, 10.1 (2009), pp. 23-55; Andrew Hardie, Tony McEnery and Scott Songlin Piao, 'Historical text mining and corpus-based approaches to the newsbooks of the Commonwealth', in The Dissemination of News and the Emergence of Contemporaneity in Early Modern Europe, ed. Brendan Dooley (Farnham: Ashgate, 2010), pp. 251-86.

6 For a description of the $Z E N$ corpus, see Udo Fries, 'Newspapers from 1665 to 1765 ' in Facchinetti et al, News as Changing Texts, pp. 49-90.

$7 \quad F E E N$ and $L N C$ are found at <cqpweb.lancs.ac.uk> [18/11/15]. For a description of CQPweb, see Andrew Hardie, 'CQPweb—combining power, flexibility and usability in a corpus analysis tool', International Journal of Corpus Linguistics, 17.3 (2012), pp. 380-409.

8 Raymond Hickey, Corpus Presenter Software for Language Analysis (Amsterdam: John Benjamins, 2003). The use of different software for different corpora often becomes increasingly tricky the more complex the research question. All corpus analysis tools can provide straightforward concordances but not all of them offer similarly-designed resources for analysing more complex lexical and syntactic issues. 
to 400 words, while with $Z E N$ the possibilities of opening up the text are even greater. $Z E N$ is not a web-based corpus and, therefore, the copyright restrictions are less stringent.

The possibility provided by all three corpora to look beyond the single concordance line was crucial in this analysis, since the additional contextual information was sometimes necessary to disambiguate the semantic field of 'letter\{s\}'. For example, as my research question involved the examination of the interrelationship between epistolary and print news I did not want my analysis to be skewed by references to 'letter\{s\}' where the search term had no relation to published news. Thus, the extraneity of the following occurrence of 'letter' to my analysis only became clear by reference to the entire sentence in which it was found:

1. Don Descant presently rode to the Prince to Wurtzburch, to show him the $\{$ Letter $\}$, and on Saturday last came hither again ${ }^{9}$

Had the concordance been restricted to the standard four or five words to the left and right of the search word it would have been frequently impossible to determine the full semantic scope of 'letter\{s\}'.

In concluding this methodological overview, it is necessary to underline that, as with much diachronic corpora-based research, this study does not presume to provide an exhaustive analysis of the research question. The conclusions are based on a selected number of corpora, which by their very nature provide only a partial view of the millions of words found in seventeenthcentury periodical news. Apart from this, I am also aware that in basing my study of print epistolary news on an examination of the search words 'letter $\{s\}$, I am leaving out of consideration textual references to printed correspondence which are lexicalised in different ways. Thus, this analysis does not incorporate possible references to correspondence in such expressions as 'From Warsaw they write', 'We have advice that', 'From Spain we have an account that'. However, this focus on the terms 'letter\{s\}' can be justified on both theoretical and practical grounds. First, the number of occurrences of the search term in the corpora is high enough to accommodate a detailed, wide-ranging analysis. Secondly, on a practical level, the examination of a simple search word in a concordance is much less labour-intensive than a full examination of all possible references to epistolary news in the various corpora. One of the most invaluable benefits of the growing accessibility of historical news electronic

9 Corante, or, newes from Italy, Germany, Hungaria, Bohemia, Spaine and Dutchland, 2 August 1621 (FEEN corpus). 
corpora and archives is that it allows researchers to identify quickly and efficiently general traits and features of historical news discourse, and how such discourse changed over time. This overview can then, if desired, be supplemented by more specific textual studies of particular news publications and chronological periods.

III

Taken as a whole, the FEEN, LNC and ZEN corpora contain 1,860 occurrences of 'letter\{s\}. Out of this total figure, 'letter\{s\}' is associated with published news in $75^{-80} \%$ of the occurrences, where the range reflects occasional difficulty in deciding whether or not the epistolary correspondence can be classified as an editorial news source.

Typical examples of the referencing to 'letter $\{\mathrm{s}\}$ ' as an editorial news source include:

2. An Extract of a \{letter $\}$ from Brunswick the 24. of Iuly, the 3. of August $\mathrm{t}^{10}$

3. From Venice the 6. of Iuly 1621 . \{letters\} from Millane certifie, that ${ }^{11}$

4. By \{letters $\}$ from Holland we are advised, That Eight great Fly-Boats laden with Salt ${ }^{12}$

5. By $\{$ Letters $\}$ not received till then, but dated on the second of this Moneth $^{13}$

The typicality of these extracts, which will be discussed in more detail later in the section, is seen in referencing to the place and date of the original correspondence. Sometimes both features would be supplied in the print news, as in (2) and (3), while in other instances either one or the other would be given. Thus in (4) we find a reference to where the letters had come from, while in (5) it is the date that is supplied.

Table 17.1 shows the frequency of the occurrence of the terms 'letter $\{s\}$ ' between 1620-91. The higher frequency of 'letters' as opposed to 'letter' in all four periods is significant. The use of the plural form indicates that when news writers referred to correspondence as a source of news they were more frequently basing their information not on just a single letter but on multiple epistolary

\footnotetext{
10 Cent. 4. Numb. 30, 4 August 1641 (FEEN).

11 Corante, or, newes from Italy, 2 August 1621 (FEEN).

12 The Protestant (Domestick) Intelligence, 1 March 1681 (ZEN corpus).

13 Mercurius Aulicus, 7 January 1643 (FEEN).
} 
TABLE 17.1 Occurrences of 'letter' and 'letters' (1620-91). The figures are measured pm (per million words). ${ }^{14}$

\begin{tabular}{lll}
\hline Time & Letter & Letters \\
\hline $1620-41$ & $450 \mathrm{pm}$ & $900 \mathrm{pm}$ \\
$1642-49$ & $450 \mathrm{pm}$ & $550 \mathrm{pm}$ \\
$1653-54$ & $300 \mathrm{pm}$ & $750 \mathrm{pm}$ \\
$1671-91$ & $300 \mathrm{pm}$ & $700 \mathrm{pm}$ \\
\hline
\end{tabular}

texts. Of course, it is not possible to know whether or not this was true in practice, but the fact that it was written is nevertheless significant. Reference to multiple letters as a news source gave credibility both to the news writer and to the news itself. The news writer is presented as someone whose seriousness and professionalism is seen in the practice of sifting through the various letters arriving from a particular place and recounting, or at least relaying, the news on the basis of these multiple sources. As a result, the published news is presented as not the account of one personal viewpoint but instead as a composite picture of assorted epistolary news. Unless a single epistolary source carried particular weight or prestige, a dispatch or report based on multiple epistolary sources could be preferred since partiality was less likely. ${ }^{15}$

The information relating to 'letter $\{\mathrm{s}\}$ ' in the concordances falls into nine broad categories. The categories are as follows: provenance of letter ("From Berlin", "From Norimberg"), date of letter ("from Reading Ian. 19", "yesterday", "lately"), communicative function of letter ("The letters from Silesia certifie", "Our Dutch letters of the 30 instant say"), contents of letter ("From Berlin letters affirme that part of the Duke of Saxons Army is going"), author of letter ("The Gentlemans letter begins thus"), addressee of letter ("In this letter there was a paper writ by a great Papist in Ireland to his friend"), mode of arrival ("express", "enclosed in another Merchants letter", "intercepted"), reproduction of letter ("copie", "extract"), and private/public nature of letter ("private letters from Amsterdam"). ${ }^{16}$

14 The figures are measured in 10os and 5os since any more precise calculation would be unjustified given the occasional difficulty in determining whether the presence of 'letter\{s\}' represented an editorial news source.

15 For further discussion of this, see pp. 403-4.

16 I use the term 'author' rather than 'writer' since with much official correspondence of the time it is probable that the physical act of letter writing was carried out by an amanuensis. 
The first three fields (provenance of letter, date of letter, communicative function of letter) occur very frequently and the fourth field (letter contents) almost always, whilst information relating to the last five categories is only occasionally found. Given restrictions of space, it is not possible in the present chapter to analyse the myriad themes making up letter contents, but the other eight fields are examined below, with particular attention given to the first three most frequently occurring categories.

\section{(i)}

Provenance of Letter

Information regarding the provenance of epistolary news is given throughout the period under review. Between $1620-54$, details regarding place are often coupled with information as to when the correspondence was sent. In the FEEN corpus for the years 1620-41, the spatial information usually precedes temporal details, while in the FEEN and $L N C$ corpora of the 1640 and $1650 \mathrm{~s}$ there is no typical order of information.

6. By $\{$ letters $\}$ from Breslaw in Silesia, dated Octob. 13, the Imperialists thus write $^{17}$

7. in the $\{$ letters $\}$ from the Hage, Octob. 21. which say, That ${ }^{18}$

8. Munday Ian. 12. By \{letters\} out of Ireland we had the confirmation of a late great defeat ${ }^{19}$

9. By $\{$ letters $\}$ from the North, dated at the Leaguer before Yorke, the 12. of July 20

10. Last Wednesday here arrived \{letters\} from the Lords Ambassadors in England, being dated the 20 of this month ${ }^{21}$

In the $Z E N$ corpus for the years $1671-91$, the provenance of the letters is very frequently given; much less common is for this to be coupled with information regarding the date.

11. There are \{letters $\}$ from Copenhagen, which tell us that the King of Danemarke had expected his Brother the King of Sweden ... ${ }^{22}$

12. $\{$ letters $\}$ from France do continually repeat the lamentable Pressures ${ }^{23}$

\footnotetext{
17 A Continuation of the Newes of this Present Weeke, 16 November $1622($ FEEN).

18 A Continuation of the Newes of this Present Weeke, 16 November 1622 (FEEN).

19 Mercurius Civicus, 15 January 1645 (FEEN).

20 The Kingdomes Weekly Intelligencer, 16 July 1644 (FEEN).

21 Mercurius Politicus, 6 April 1654 (LNC).

22 The London Gazette, 8 December 1681 (ZEN).

23 The Protestant (Domestick) Intelligence, 8 February 1681 (ZEN).
} 
In Table 17.2 we see the places which are most frequently cited as being the geographical source of epistolary news. The broad classification is ordered alphabetically, since any attempt to establish a strict numerical order of the most frequently cited places is beset by various methodological issues, the most significant being difficulties in determining whether each time a place is cited that occurrence amounts to a new news story (or at least a development of the same story). For example, the town 'Lime' is not included in the $L N C$ classification since, although numerically it occurs frequently, each of the occurrences refers to just one specific news story. ${ }^{24}$

It is interesting that between 1620 and 1641 one of the most cited geographical locations is Vienna, the capital of the Habsburg empire, which throughout the period was enmeshed in the struggle against Protestant forces in the Thirty Years War. These references to Vienna show that during 1620-41 English news readers - the vast majority of whom supported the Protestant cause-were being informed of epistolary news originating not just from Protestant centres

TABLE 17.2 Ten most frequently cited source locations of epistolary news in FEEN, LNC and ZEN corpora.

\begin{tabular}{llll}
\hline $\mathbf{1 6 2 0}-\mathbf{4 1}$ & $\mathbf{1 6 4 2 - 4 9}$ & $\mathbf{1 6 5 3 - 5 4}$ & $\mathbf{1 6 7 1 - 9 1}$ \\
\hline Amsterdam & Bristol & Amsterdam & Brussels \\
Brussels & Holland & Dover & Constantinople \\
Genoa & Ireland ${ }^{25}$ & Edinburgh & Dublin \\
Hague & London & Harwich & France \\
Leipzig & Newark & Holland & Poland \\
Nuremberg & Northampton & Ireland & Riga \\
Prague & out of/from the & Paris & Rome \\
& North & & \\
Regensburg & out of/from the & Plymouth & Spain \\
& West & & \\
Venice & Reading & Scotland & Transylvania \\
Vienna & York & Sweden & Upper Hungary \\
& & & \\
\hline
\end{tabular}

24 The story, involving the attack on a Dutch ship by an English frigate in January 1654, was reported in seven different publications in the $L N C$ corpus.

25 This only refers to the single word 'Ireland', and does not take into consideration multiword references like 'Dublin in Ireland'. 
in northern Europe, such as Amsterdam and the Hague, but also from the imperial capital. ${ }^{26}$ Although English coranto publishers were convinced supporters of the Protestant cause, they provided their readers with news from opposing political camps. For much of the seventeenth century, English readers' understanding of Europe was based on their ability to assimilate and interpret information coming in from different locations and written by multiple correspondents, not infrequently presenting contrasting facts and points of view. Indicating the provenance of epistolary news was not just important in that it provided the seventeenth-century reader with initial information about where the news story originated, but more importantly - at least for the knowledgeable reader - the ideological slant that the story might contain. News readers were often given a composite, even contradictory picture of an event and it was their task-or their right — to interpret for themselves what they read. This is recognised by the editor of a coranto of 31 January 1623:

13. Gentle Reader, we must aduertise you that in our Newes we deliuered some things in seuerall places as wee get the tidings in seuerall parts, to shew you how the parties agree in their relations, seeing it is knowne that many write partially, and the one addes some circumstances more then the other; and hereafter we will put down very exactly from whence euery thing commeth. For you must conceiue we set downe some things as we receiue them from the High Dutch Copies, and some from the Low Dutch, printed at Antwerpe which peraduenture may speake partially, which I desire you to take notice of, and to iudge accordingly: and so farewell. ${ }^{27}$

In complete contrast to corantos from 1620-41, in the FEEN corpus of newsbooks from ${ }^{1642-9}$ the provenance of epistolary news is almost exclusively British. The most frequently cited British location is London, but it is only indicated as a news source in the Oxford-printed royalist pamphlet Mercurius Aulicus. The other news publications in the corpus are all published in London, and would therefore have no reason to refer to the town as an epistolary source. Apart from the towns indicated in Table 17.1, the place names also include

26 Editorial recognition that some coranto readers supported the imperial cause is seen in the following editorial notice: 'Gentle Readers: for there are two sorts of you I know: the one wishing well to the Emperor and his proceedings: the other, murmuring and repining that the Palatines cause and Bohemias businesse thrives no better', The Affaires and Generall Businesse of Europe (24 February 1624). 1625), where the editor writes: "For I translate onely the Newes verbatim out of the 
some smaller locations caught up in the Civil Wars (Litchfield, Abington, Banbury Castle and Tickhill Castle). The 1640 s corpus also provides several examples of generically defined geographical areas such as 'from the West', 'from the North', as well as non-specific references like 'from divers places' and 'from other parts'.

The provenance of epistolary news in the $L N C$ corpus of $1653^{-4}$ contrasts with both the findings of the 1640 s and the two earlier decades. Whereas provenance in $1620-41$ is restricted to continental Europe, and in the 1640 s is focused on the British Isles, in 1653-4 we see numerous references to epistolary news originating from both these areas. Readers were receiving a more wideranging account of contemporary events. The British sources of epistolary news include not only large towns such as Edinburgh, Newcastle and Bristol but also ports such as Dover, Plymouth, Falmouth and Lime. The ports provided correspondence about the naval conflict involving the English, French and Dutch:

14. By $\{$ Letters $\}$ of this Day from Dover it was advertised, that two of our Frigates met with two Merchants Men of France ${ }^{28}$

15. The last $\{$ Letters $\}$ from Falmouth say, that two Dutch Prizes, and one French Prize are brought in thither ${ }^{29}$

In the European letters we frequently find examples of an embedded epistolary network whereby English readers receive epistolary news from a foreignbased correspondent, who in turn refers to newsletters arriving from somewhere else.

16. By $\{$ Letters $\}$ from Frankfort thus ... Our last $\{$ Letters $\}$ from Poland advise us that as yet they have not any tidings ${ }^{30}$

Tongues or Languages in which they are written, and hauing no skill in Prognostication, leaue therefore the judgement to the Reader, \& that especially when there are tidings which contradict one another". The same viewpoint is also expressed in the editorial of the first issue of the Daily Courant, England's first daily newspaper, where the editor writes that he will "give his Extracts fairly and Impartially; at the beginning of each Article he will quote the Foreign Paper from whence 'tis taken, that the Publick, seeing from what Country a piece of News comes with the Allowance of that Government, may be better able to Judge of the Credibility and Fairness of the Relation" (11 March 1702).

28 Certaine Passages of Every Dayes Intelligence, 10 February 1654 (LNC).

29 Certaine Passages of Every Dayes Intelligence, 3 February $1654(L N C)$.

$30 \quad$ Perfect Diurnall of Some Passages and Proceedings, 3 April 1654 (LNC). 
Therefore, in this particular case the English news buyer is reading news based on letters from Frankfurt, which in turn include information found in letters from Poland. Epistolary news is travelling across Europe and eventually reaching the English reader, but, as will be examined in more detail in the following section, the time involved in the transmission of the news may impact on how the news is received by the English audience.

Foreign correspondents occasionally refer to letters sent by their own countrymen from England, thereby giving English readers a foreign perspective on their own affairs. For example, the passage below reports on letters that Dutch ambassadors in England sent back to the Hague regarding the peace treaty between England and the United Provinces.

17. From Rotterdam, April 24. stilo novo.

On the 14 of this Month arrived an Express at the Hague, with \{Letters\} from our Lords Ambassadors in England to the States General, wherein they advise that the Peace was wholly finished and concluded ${ }^{31}$

However, foreign-based correspondents referring to English epistolary news could also be part of the English diplomatic network. Marchamont Nedham, the editor of the state newsbook Mercurius Politicus, had access to some of the English diplomatic correspondence sent back to the Secretary of State in London, and would include extracts of such correspondence in his weekly newsbook. ${ }^{32}$ The extract below is part of a letter that an English Hamburgbased diplomat sent back to his superior in London. As was common in diplomatic correspondence, the letter begins by first referring to what letters had arrived from England and then provides a brief update on the news contained in the diplomat's last letter. As epistolary transmission was at the mercy of not just natural hazards, which could at any moment prevent letters from concluding their journey across land and sea, but also interception and theft, the diplomat had to provide details about what correspondence he had both recently received and sent. ${ }^{33}$

$31 \quad$ Mercurius Politicus, 27 April 1654 (LNC).

32 Fraser, The Intelligence of the Secretaries of State, 39; Joad Raymond, 'Marchamont Nedham', ODNB, <www.oxforddnb.com/view/article/19847> [18/11/13]; Brownlees, 'Capt. Badiley's answer', pp. 157-61.

33 Nicholas Brownlees, 'Reporting the news in English and Italian personal newsletters', in Letter Writing in Late Modern Europe, eds. Marina Dossena and Gabriella Del Lungo Camiciotti (Amsterdam: John Benjamins Publishing, 2012), pp. 121-38. 
18. From Hamburgh May 12. Stilo novo.

We had no \{Letter\} last week from England; the Parquet was Robbed about Brussels, and most Letters opened: Some State-Thieves (I believe) met with it. As I wrote in my last, my Lord Ambassador Whitlock hath now finished the Affair at Upsall. ${ }^{34}$

Apart from geographical provenance, the 1653-4 corpus also provides the first examples of epistolary ship news, which over the next decades was to become an important source of information about distant lands and seas. Sometimes readers are told from which ship the letter was written, in other cases the reference is more generic.

19. By \{Letters $\}$ from on board the Swift-Sure, dated the 13 of January 1653 was certified the Examinations of some foreign Ships that came in to find Market for Deals, Pitch ... ${ }^{35}$

20. A \{Letter $\}$ from the Squadron in the West. Sir, About four days since two ships belonging to the Dutch sailing from Holland towards France passed by $\mathrm{us}^{36}$

What stands out in the analysis of the provenance of 'letter $\{s\}$ ' in the $1653-4$ corpus is the diversity of source locations. The epistolary network appears to be expanding exponentially and news readers are tapping into correspondence arriving from an ever-widening geographical area. This ever-greater diffusion of epistolary news is reflected in the print advertisements in the 1653-4 corpus that promote competitive postal rates and services throughout the British Isles. In the newsbook extract below, John Manley, the Protectorate's officer in charge of the 'Posts of this Nation', provides the rates for correspondence from London to 'Oxford, Cambridg, Southampton, Winchester, Lye, Yarmouth, Norwich, and the places upon those Roads, as to any of the other Roads of England, Scotland and Ireland'.

21. The Rates of Letters.

To any place within 80 miles distance, $2 \mathrm{~d}$. a single Letter, $4 \mathrm{~d}$. a double Letter. To a further distance $3 \mathrm{~d}$ a single Letter, $6 \mathrm{~d}$. a double Letter. To Scotland 4d. a single Letter, 8d. a double Letter. To Ireland 6d. a single Letter, 12 d. a double Letter. ${ }^{37}$

\footnotetext{
34 Mercurius Politicus, 18 May 1654 (LNC).

35 The True and Perfect Dutch Diurnall, 24 January 1654 (LNC).

$36 \quad$ Perfect Diurnall Occurrences, 29 May 1654 (LNC).

37 Weekly Intelligencer of the Common-wealth, 10 January 1654 (LNC).
} 
In the 1671-91 ZEN corpus, the geographical provenance of print letters is further extended. We find references not only to the more distant regions of Europe but also beyond. Towns, regions and countries include Aliant, Barbados, Cadiz, Chavenny on the borders of the Valtoline, Confines of Transylvania, Constantinople, Copenhagen, Corfu, Levant, Leeward Isles, Lisbon, Malaga, Malta, Moscow, Riga, Stockholm, Tunis, Ukrania, Upper Hungary. Since newspapers of the period focused on foreign news there are fewer British and Irish locations, but the few that are found include towns and places such as Exon, Thirsk and Lewis, which previously had not been mentioned in the epistolary network.

If we now look back over the seventy years separating the first publications in the 1620 from those in the 1671-91 corpus, we can see four broad patterns. In the 1620 and 1630 s the letters arrive from the United Provinces, the Habsburg Netherlands, Paris, Germany, Italy, and central Europe, with much of the news relating to matters concerning the Thirty Years War. In contrast, in the 1640 s not only do readers find fewer references to letters as a source of news, but when they are found they refer almost exclusively to English locations, in particular those involved in the Civil Wars. In the 1653-4 corpus we find a greater use of letters as a news source than in the previous decade, with correspondence arriving in broadly equal measure from the British Isles (in particular Scotland) and abroad (especially the United Provinces). The 1653-4 corpus also illustrates how by this stage the epistolary news network incorporated not only domestic ports but ship news too. What is evident in the $1671-91$ corpus is the degree to which news publishers tapped into a network of news stretching right across Europe. In these decades English news readers receive epistolary news not just from the main postal hubs of previous decades but also from the most distant reaches of continental Europe. The newspapers provide a much more panoramic view of events occurring throughout the European continent than in previous years, as well as more regular mention of events from the other side of the Atlantic Ocean.

\section{(ii) Date of Letter}

This section focuses on the information that news publications provide as to when letters were sent. Most frequently we find the precise day of the month, but in other instances either a time reference or the expression 'last letters' is given.

22. And by $\{$ letters $\}$ from the Hage the 20. of May, it appeares he was since againe at Hildeshem ${ }^{38}$

23. It was also certified this day from Newarke, by \{letters $\}$ of the 6 of June ${ }^{39}$

38 A Continuation of More Newes From The Palatinate, 13 June 1622 (FEEN).

39 Mercurius Aulicus, 15 June 1644 (FEEN). 
24. It was advertised by \{letters $\}$ late this Evening, that the Scots ... should come in to hinder $\mathrm{it}^{40}$

25. Our last $\{$ letters $\}$ from Poland give an Account, that the Negotiation ... advanced not ${ }^{41}$

From a quantitative point of view, seventeenth-century news readers receive less information about when the letters were sent than about their provenance. The two periods in the three corpora when they are given most details about time are between 1622-4, when the weekly news was being edited and written up by Thomas Gainsford, and between 1643-4 in the royalist Mercurius Aulicus publications.

Possible explanations for this include the desire on the part of both editors to emphasise by means of this additional temporal information the professionalism of their work and the reliability of their news. This is certainly what is implied in this editorial notice of June 1622:

26. Wee write a continuation, that you may see by the proceedings, that there is good dependency between the relations, wherein we purpose to keepe nere to the Lawes of Historie, to guesse at the reasons of the actions by the most apparant presumptions, and to set downe the true names and distances of places, and times, that you may perceiue, there is probability in the seuerall Atchieuements. ${ }^{42}$

As epistolary news in Mercurius Aulicus was limited to letters travelling within the British Isles, the time lapse between the sending of the letters and their arrival at the editor's desk was considerably less than was the case with the 1622-4 corantos, where the letters arrived from continental Europe. ${ }^{43}$ In Mercurius Aulicus the time between the dispatch and arrival of the letter is usually given as between three to six days (though we are not told from where the letters were sent), whereas in the 1620 s publications the time range was much greater. As exemplification of this, in the concordance lines (27) and (28) the time lapse between the dispatch of the letter and its reporting in Mercurius Aulicus is three and six days respectively, while in (29) the intervening time

\footnotetext{
40 Mercurius Aulicus, 15 June 1644 (FEEN).

41 The London Gazette, 12 May 1681 (ZEN).

42 A Continuation of More Newes, 13 June 1622 (FEEN).

43 Censorship restrictions prevented corantos from publishing news relating to domestic affairs.
} 
between the sending of the letter on 8 October and its publication in the coranto of 16 November is over 5 weeks.

27. TUESDAY. Jan. 17. By $\{$ letters $\}$ dated Jan. 14. it was this day certified ${ }^{44}$

28. TUESDAY. Jan. 3. This day by \{letters\} sent from Colonell Hastings, bearing date the 28 . of December ${ }^{45}$

29. yet neverthelesse the $\{$ letters $\}$ from Vienna, Octob. 8 relate, that after the Emperour ... ${ }^{46}$

Unsurprisingly, the further away from England, the longer the letters took to reach the London editor, though it would be rash to attempt to calculate exact times of transmission of epistolary news from continental Europe to London on the basis of references in the corantos. First, the editor makes no mention as to when the letters actually arrived in London, and, secondly, the concurrent use of both the Julian and Gregorian calendars in Europe often distorts calculations, since there is frequently no certainty as to which of the calendars was being adopted by the correspondent in question.

In the 1653-4 and 1671-91 corpora we find numerous instances of news reports referring to letters which in turn refer to news contained in other letters. These embedded levels of epistolary news, which have already been considered in relation to provenance, impact on the time separating the original event from its reporting in the English press. For example, in the Mercurius Politicus dated 22 December 1653, there is a dispatch from "Gottenburgh, Novemb. 21. S.v." that contains the lines: "By Letters from Stockholm I have, that there were 3 Hollands Flyboats lading with great Guns for Holland. I have acquainted his Excellency with it, and doubt not but some course will be taken for the interception of the same". The original event - the lading of " 3 Hollands Flyboats" - has no specific time reference other than the fact that it must have occurred at some time before the sending of the letters from Stockholm, which were then referred to in the dispatch from Gottenburg, in turn printed at a later date in Mercurius Politicus. As this very circuitous transmission of the original news extended the temporal distance separating the reading of the event from its occurrence, it is worth considering whether the issue of time plays a role in a reader's understanding and reception of news. Where the time lapse is extensive, does the reader interact with what is being reported in the same way as when the time lapse is much shorter?

\footnotetext{
44 Mercurius Aulicus, 21 January 1643 (FEEN).

45 Mercurius Aulicus, 7 January 1643 (FEEN).

46 A continuation of the newes, 16 November 1622 (FEEN).
} 
Recent research in construal level theory (CLT) would suggest that this is the case. Liberman et al. have demonstrated that distance, including temporal distance, affects the way in which we construe an event. ${ }^{47}$ In particular, CLT argues that the 'more distant events are represented on a higher-level, that is, more abstractly, with less concrete, contextual details' ${ }^{48}$ This results in a less nuanced, more extreme view of events, activities and behavior situated in the past. Studies have yet to be carried out on how temporal distance affects the reception of news, but given the likelihood of such an interrelationship we need to bear in mind that English readers were sometimes reading of European events that temporally belonged to a past that was both distant and vague. This might well have influenced their understanding of European news.

\section{(iii) Communicative Function of Letter}

The communicative function of epistolary news is most directly expressed by the verbs writers use to explain what it is that letters do. In many instances these are common communicating verbs such as 'say', 'tell', 'inform', 'speak of', 'make mention'. Another verb that is frequently found is 'advertise', which in early modern usage had the meaning of 'inform'.

30. The English Post is newly come, and our \{letters\} tell us, that all hopes of an accommodation are laid aside ${ }^{49}$

31. The $\{$ letters $\}$ which came the same day from Bordeaux, inform us that ${ }^{50}$

32. And it was further advertised in the said \{letters\}, that notwithstanding they had sent Propositions ${ }^{51}$

The predictability of such verbs in relation to 'letter\{s\}' explains why in the cases where there is no verb there are no problems of comprehension. In the lexical gap created by the absence of the verb, the reader mentally inserts one of the common communicating verbs that frequently occur with 'letter $\{\mathrm{s}\}$ '.

47 Nira Liberman, Yaacov Trope and Elena Stephan, 'Psychological distance', in Social Psychology: Handbook of Basic Principles (2nd ed.), ed. Arie Kruglanski and Edward Higgins (New York: The Guilford Press, 2007), pp. 353-81.

48 Tal Eyal, Nira Liberman and Yaacov Trope, 'Judging near and distant virtue and vice', Journal of Experimental Social Psychology, 44 (2008), p. 1205. See also Nira Liberman, Michael Sagristano and Yaacov Trope, "The effect of temporal distance on level of mental construal', Journal of Experimental Social Psychology, 38 (2002), pp. 523-34.

49 Mercurius Politicus, 29 December 1653 (LNC).

50 Mercurius Politicus, 6 April 1654 (LNC).

$51 \quad$ Mercurius Aulicus, 11 February 1643 (FEEN). 
33. Concerning our Fleet by $\{$ Letters $\}$ from Portsmouth thus, General Blake and General Monk being now at London ${ }^{52}$

34. By $\{$ Letters $\}$ from Holland as follows, Here hath again been a great loss to this Country, both by fire and water ${ }^{33}$

Apart from the above-mentioned communicating verbs, we also find the use of verbs such as 'confirm', 'affirm' and 'certify' in relation to epistolary news. ${ }^{54}$

35. From Berlin \{Letters affirm that part of the Duke of Saxons Army is going with the Generall Bannier ${ }^{55}$

36. The last \{Letters $\}$ from Lyons do confirm unto us the great division happened lately in Avignon 56

37. $\{$ letters $\}$ this day from the North certifie, that the Garisons of Carlisle ...57

38. By \{letters $\}$ of the 21. from Genua it is certified, that Petro de Liena is arrived there with two galleys ${ }^{58}$

These verbs are not merely simply communicating news but attesting its truth. 'Certify', in particular, underlines the truth value of the epistolary information. Defined in the $O E D$ as "to make (a thing) certain; to guarantee as certain, attest in an authoritative manner; to give certain information of", 'certify' emphasises the difference between epistolary news and other forms of news. ${ }^{59} \mathrm{~A}$ letter could indeed 'certify' news contained within it since, as a genre, epistolary news was recognised as being capable of transmitting news of the highest reliability. ${ }^{60}$ The same could not be said for ordinary spoken news or for much of

$5^{2} \quad$ The True and Perfect Dutch Diurnall, 17 January 1654 (LNC).

53 The True and Perfect Dutch Diurnall, 24 January 1654 (LNC).

54 The use of the single quotation mark indicates all possible forms of the base form of the verb (e.g. 'confirm', 'confirms', 'confirmed').

55 The Continuation of Our Weekely Intelligence, 29 November 1631 (FEEN).

56 Perfect Diurnall of Some Passages and Proceedings, 26 December 1653 (LNC).

57 Mercurius Pragmaticus, 26 September 1648 (FEEN).

$5^{8}$ Corante, or, Newes from, Italy, Germany, Hungarie, Spaine and France, 24 September 1621 (FEEN).

59 Oxford English Dictionary <www.oed.com> [10/11/15]. As an early seventeenth-century example of this definition of 'certify', the $O E D$ gives ' 1603 P. Holland tr. Plutarch Morals 282 (R.) [To] certifie that Arion was alive and safe'.

6o Atherton, 'The Itch Grown a Disease', pp. 46-7; Schneider, The Culture of Epistolarity, pp. 146-7; Joad Raymond, 'News', in The Oxford History of Popular Print Culture, ed. Raymond (Oxford: Oxford University Press, 2011), p. 396; Pettegree, Invention of News, pp. 316-8. 
print news, and it is no coincidence that in all three corpora (FEEN, LNC and $Z E N)$ 'certify' collocates with 'letter\{s\}' much more often than with other modes of news transmission.

The subcorpus in which the collocation of 'letter\{s\}' and 'certify' is most evident is in the Mercurius Aulicus newsbooks of 1643-4.

39. By $\{$ letters $\}$ also of the same date, it was certified, that on Munday the 16 of Jan. ${ }^{61}$

40. It is further certified in the said \{letters\}, that some Constables of that County had beene imprisoned ${ }^{62}$

A possible explanation for this foregrounded collocation of 'letter $\{\mathrm{s}\}$ ' and 'certify' in Mercurius Aulicus lies in the newsbook's role during those years. Between 1643-4 the Oxford-based newsbook had to form, develop and consolidate public opinion around the king's standpoint, and to do so it needed to convince its readers that what they read of Royalist successes and Parliamentarian defeats and outrages corresponded to the truth. The use of 'certify' therefore had the function of both guaranteeing and reinforcing the pro-Royalist news arriving in Oxford from correspondents around the country. ${ }^{63}$

The role of epistolary news in corroborating information is further seen in the two quotations below, where the writers candidly admit that the information is currently only rumour, which can only be corroborated by epistolary confirmation.

41. to witnesse the truth of this, we have not as yet received any \{letters\} which every hour are expected ${ }^{64}$

42. but whether it be true, and who these murderers may be is, yet unknown: The English \{letters\}, by whom the confirmation thereof was expected, being neither on Saturday last, nor to day come on ${ }^{65}$

$61 \quad$ Mercurius Aulicus, 28 January 1643 (FEEN).

62 Mercurius Aulicus, 28 January 1643 (FEEN).

63 As well as 'certify', in Mercurius Aulicus we also find numerous instances of 'signify' collocating with 'letter', for example: "And it is signified in the same \{letters\} also, that the Earle of Northumberland ..." The editor-who makes very little use of standard communicative verbs such as 'say' and 'tell' in relation to epistolary news - may have felt that 'signify', like 'certify', helped to underline the reliability of the pro-royalist news.

64 Mercurius Britanicus, 7 October 1644 (FEEN).

65 Mercurius Politicus, 12 January 1654 (LNC). 
However, despite the high esteem in which epistolary news was held, there were occasions when it too was no guarantee of truth.

43. News is come, and probablie true, by $\{$ letters $\}$ directed to some Members of Parliament 66

(iv) Author of Letter

Only occasionally is information given about the letter's author, but when mentioned in the corpora, authors fall into six main categories. The three with the highest number of occurrences are political figures and diplomats, merchants, and soldiers of varying ranks. Examples include:

44. Here is arrived a Turkish Messenger with \{letters\} from the Grand Visier ${ }^{67}$

45. The last Sunday arrived here an express from London, with $\{$ Letters $\}$ from the Lord Beverling 68

46. Concerning the \{letter\} from the Marchants factor of London ${ }^{69}$

47. We haue since preremptorilie heard, by \{letters $\}$ written from a Dutch Merchant resident in Vienna ${ }^{70}$

48. The Copie of a \{Letter $\}$ which Count Henry vanden Bergh, Generall of his Majesties Army, wrote ${ }^{71}$

49. In the end is added a comparison of two souldiers \{letters\} concerning former occurrences ${ }^{72}$

Politicians (including heads of state), diplomats and generals are usually named whereas merchants and common soldiers are not. What gave importance to the latter two groups was not who they were but what they did. As both had important roles in the reporting of news, their correspondence was considered valuable. A soldier could provide an eye-witness appraisal of a military situation while the merchants' many contacts, both domestic and foreign, allowed them access to wide-ranging, often privileged information.

The fourth and fifth categories of authors are made up of ship captains and gentlemen. As said in section III (i) ship news first appears in the $L N C$ corpus

\footnotetext{
66 Mercurius Britanicus, 17 June 1644 (FEEN).

67 The London Gazette, 2o February 1671 (ZEN).

68 The Faithful Scout, 24 February 1654 (FEEN).

69 Newes of Europe, 12 March 1624 (FEEN).

70 A Continuation of the Newes, 16 November 1622 (FEEN).

71 The Continuation of our Weekely Avisoes, $6 \mathrm{July} 1632$ (FEEN).

72 A Continuation of More Newes, 13 June 1622 (FEEN).
} 
(1653-4), where details in the news item can include not only the name of the ship but also sometimes its captain.

50. By Letters from Captain Foster, Commander of the Phoenix Frigate ${ }^{73}$

Letters are come from Capt. Potter, Commander of the Constant Warwick, that he hath with the loss of three men, after seven hours fight ${ }^{74}$

The two examples of 'gentlemen' as authors are found in corantos from 1622-4. This is no coincidence since in the sixteenth and first part of the seventeenth century an author's social standing could alone endow the reported news with significance. ${ }^{75}$ As a 'gentleman' was recognised as having social prestige, his correspondence was deemed of value.

51. The Gentlemans \{letter\} begins thus: The King crossed the Rhine at Gernsheim ${ }^{76}$

52. which is two \{letters\}, one from an Ancient, and another from a Gentleman of a Company ${ }^{77}$

In the sixth category we find the metonymic use of 'hand' as substitute for the author of the correspondence.

53. Tuesday March 28. By Letters from a good hand thus. Sir, The sad spectacle, which I have generally beheld throughout most parts of Ireland ${ }^{78}$

54. From Constantinople our \{letters\} from all hands tell us ${ }^{79}$

In 53, the 'good' in "good hand" alludes to the author's acknowledged understanding of the facts and subject matter contained in the letters. The reasons for such knowledge are not specified but given the news item in question the reader is led to infer that the author was a person whose professional role or social status ensured an insightful analysis of the topic of the letter.

73 The True and Perfect Dutch Diurnall, 17 January 1654 (LNC).

74 Several Proceedings of State Affairs, 16 March 1654 (LNC).

75 Pettegree, Invention of News, p. 317; Randall, Credibility in Elizabethan and Early Stuart Military News, pp. 49-75.

76 A Continuation of More Newes from the Palatinate, 13 June 1622 (FEEN).

77 A Continuation of More Newes from the Palatinate, 13 June 1622 (FEEN).

78 Mercurius Aulicus, 3 April 1654 (LNC).

79 The London Gazette, 16 February 1671 (ZEN). 
Where no details are given as to the authors' identity, it is probable they would have belonged to one of three further groups of people. Many of them would have been intelligence gatherers who, for payment or otherwise, passed information to diplomats who then used this information in their own reports back to their respective Secretaries of State, who in turn passed some parts of the reports to the press for publication. This is particularly true from the $1650 \mathrm{~s}$ onwards, when English Secretaries of State started receiving foreign diplomatic correspondence on a more regular, professional basis. ${ }^{80}$ The second category of authors comprised the news editors' own contacts. In one of the illuminating editorial notices to readers in the early 1620 , the editor refers to such correspondents:

55. The dayly Letters afford matters sufficient both of pleasure and varietie ... As for such as are written to the Marchants in London from foreine Parts, according to their mixture of Businesse and Newes, I haue contracted them, as you see, and culled them out, to giue you notice of the affaires of Europe, and what is likely to be the issue of these troubles. ${ }^{81}$

Aside from diplomatic correspondence and personal contacts, the editor's other main source of epistolary news lies in the foreign news texts which were so frequently translated over the period, and especially between 1620-41. As these were translations of previously published news, the English editor would have had little or no idea as to the original source of information unless it was specified in the text itself.

\section{(v) Addressee of Letter}

In the corpora we find numerous references to news writers having received letters themselves. In the following examples, the reference to 'we' and 'received' would suggest that the letters had been sent directly to the news writer, though in practice this may not always have been the case.

56. By Letters from Litchfield we received intelligence ${ }^{82}$

57. We received last Post a $\{$ letter $\}$ from Exon ${ }^{83}$

8o See Raymond, "'Mercury with a Winged Conscience", for the 1650s, and Fraser, The Intelligence of the Secretaries of State, for the post-Restoration period.

81 A True, Plaine, and Compendious Discourse, 26 July 1622.

82 Mercurius Civicus, 15 January 1645 (FEEN).

83 The Impartial Protestant Mercury, 1 July 1681 (ZEN). 
As stated above, the news writer may have received the correspondence through a third party. Where an addressee other than the news writer is indicated, it is usually either a political or military figure, or a 'friend' (as in 58 and 59). Where it is an important political figure (for example, in 6o), the news writer sometimes states the letter is a 'copy', thereby emphasising the accuracy of the wording in the published version.

58. I have one $\{$ Letter $\}$ more, and that comes from Paris ... and it is written to a friend in London ${ }^{84}$

59. Mr: Feaks and Mr: Sympson are yet as highly resolved in their former ways as ever, say some of their $\left\{\right.$ Letters\} to their friends in London ${ }^{85}$

6o. The Copie of the Earl of Mansfields \{Letter\} sent to Don Descant to Bamberch $^{86}$

Referring to the addressee as 'friend' has an added value since in epistolary news the word had a marked positive connotation. The fact that the addressee was a 'friend' implied that what was found in the letter conformed to the author's true opinion and state of knowledge. ${ }^{87}$

\section{(vi) Mode of Transmission of Letter}

This category refers to information on how the letter was originally sent and how it ultimately arrived. Regarding the former, there are references in all three corpora to letters being sent by an 'express'. This term had multiple meanings, referring not only to the fast delivery of a single letter, or the package in which various letters were contained, but to the person entrusted with quickly delivering the letter. The third meaning is illustrated by the following introduction to a dispatch in the 1653-4 corpus: "From Genoa thus: We hear from Madrid, that an Express was come to the Court to inform his Majesty that there was landed at Coronna in Galazia".88

However, when co-occurring with 'letter $\{s\}$ ', express would seem to refer to an 'express' package containing multiple letters:

61. The last Sunday arrived here an express from London, with $\{$ Letters $\}$ from the Lord Beverling to the Lords States General ${ }^{89}$

\footnotetext{
84 Newes of Europe, 12 March 1624 (FEEN).

85 Certaine Passages of Every Dayes Intelligence, 7 April 1654 (LNC).

86 Corante, or, Newes from Italy, 2 August 1621 (FEEN).

87 Brownlees, The Language of Periodical News, pp. 16-20.

88 The True and Perfect Dutch Diurnall, 17 January 1654 (LNC).

89 The Faithful Scout, 24 February 1654 (LNC).
} 
In addition to speed of delivery, information is also provided as to how the letter was packaged.

62. I haue a \{letter $\}$ from Amsterdam which was enclosed in another Merchants $\{\text { Letter }\}^{90}$

Another aspect of transmission that is sometimes mentioned in the letters is interception. In both the 1640 s and the 1653-4 corpora, the news writer does not hesitate to admit to receiving and publishing the enemy's intercepted letters. In times of crisis, the interception of correspondence was considered invaluable since it could give the interceptor direct knowledge of the adversary's designs.

63. But that some mischief has befallen them, was found more then probable, by one of the intercepted \{Letters\} sent from Essex's Soldiers; who gives this touch unto his friend, that he was sorry to hear the bad news out of Lancashire ${ }^{91}$

64. By a $\{$ Letter $\}$ intercepted from one of their own party thus. All our Commissioned Officers are going now to their several Localities for Levies $^{92}$

Interception was by no means confined to British shores, as can be seen in the following news dispatch where the interception is presumed to have occurred in or around Brussels.

65. We had no \{Letter $\}$ last week from England; the Pacquet was Robbed about Brussels, and most \{Letters\} opened: Some State-Thieves (I believe) met with it ${ }^{93}$

\section{(vii) Reproduction of Letter}

News writers sometimes inform readers as to whether they are providing a 'copy' or 'extract' of the letter. In both cases a conscious editorial decision is taken on how to present the information. With a 'copy', the writer is merely acting as purveyor of news in that what is being presented to the reader are the

\footnotetext{
$90 \quad$ Newes of Europe, 12 March 1624 (FEEN).

91 Mercurius Aulicus, 15 June 1644 (FEEN).

92 In the 1654 corpus the London newsbooks published the intercepted correspondence of pro-Royalist forces in Scotland.

93 Mercurius Politicus, 18 May 1654 (LNC).
} 
correspondents' exact words. In contrast, when an 'extract' is provided the news writer is implicitly indicating that an editorial decision has been made regarding what to select from the letter. Given the news writers' general reluctance to assert their editorial role in the relation of important news, 'extract' is most often found with relatively unimportant news stories.

66. The Copie of the Earl of Mansfields \{Letter\} sent to Don Descant to Bamberch $^{94}$

67. Produced the Copy of a Letter from Haerlem in Holland, which gives a punctual relation of the late sad disasters which have happened in those parts $^{95}$

68. An Extract, or brief transcription of a \{Letter $\}$ written from the Rip; Amstoldam, the 8. of January, 1654. Most worthy, loving Friend ${ }^{96}$

\section{(viii) Private Correspondence}

When news writers refer to their letters as being 'private', they are underlining the high quality of their news. Private, personal correspondence was the channel most commonly adopted for the expression of one's innermost, most firmly held views, which perhaps could not be revealed to the public at large. Through the publication of what was termed 'private' correspondence readers could be let into secrets which were not otherwise known.

69. and by several private $\{$ Letters $\}$ to Merchants, they all concur that the States of Holland have fully ratified the Agreement ${ }^{97}$

70. If it be true, what some Private \{letters\} give us an account of, That the French King ${ }^{98}$

IV

The last few years have seen the creation of three important machine-readable corpora of seventeenth-century English news. Covering the period from 1620-91 the three corpora in question-Florence Early English Newspapers Corpus (1620-49), Lancaster Newsbooks Corpus (1653-4) and Zurich English

94 Corante, or, Newes from Italy, 2 August 1621 (FEEN).

95 The Faithful Scout, 13 January 1654 (LNC).

96 Mercurius Politicus, 12 January 1654 (LNC).

97 Perfect Diurnall of Some Passages and Proceedings, 17 April $1654(L N C)$.

98 The Pacquet of Advice from France, 20 April 1691 (ZEN). 
Newspaper Corpus (1671-91) — provide the historical news analyst with digitised news texts totalling more than 1,300,000 words. Although such a figure would be considered small if measured against electronic corpora containing modern-day newspapers, it is nevertheless significant in the context of early modern news print. The corpora immeasurably facilitate broad-based research relating to the discourse and contents of English print news during its formative decades. A research topic that might previously have involved months of study and bibliographical research, if it had been taken up at all, can now be investigated much more easily, quickly, and ultimately profitably.

In this present chapter I made use of these three corpora to investigate the interrelationship between correspondence and published news in English corantos, newsbooks and post-Restoration gazettes. Through an examination of concordance lines containing 'letter $\{\mathrm{s}\}$ ' in each of the three corpora it was possible to identify nine broad categories of information relating to the presence of 'letter\{s\}' in print news from 1620-91. These categories, and their examination, have provided both details of and insight into the origin, transmission, reception and communicative importance of epistolary news and its networks (both domestic and foreign) in the seventeenth-century English press. 